\title{
The Extent to Which Students Have Sufficient Awareness of E-Learning and its Relation to Self-Studying and Academic Achievement
}

\author{
Fatima Eid Al Adwan ${ }^{1} \&$ Abdelsalam Fahad Al Awamrah ${ }^{2}$ \\ ${ }^{1}$ Department of Counseling and Special Education, School of Educational Sciences, The University of Jordan, \\ Amman, Jordan \\ ${ }^{2}$ Department of Educational Administration and Foundations, School of Educational Sciences, The University of \\ Jordan, Amman, Jordan \\ Correspondence: Fatima Eid Al Adwan, School of Educational Sciences, The University of Jordan, Amman, \\ Jordan. E-mail: f.aladwan@ju.edu.jo
}

Received: September 9, 2017

Accepted: December 20, 2017

Online Published: December 29, 2017

doi:10.5539/mas.v12n1p137

URL: https://doi.org/10.5539/mas.v12n1p137

\begin{abstract}
Rapid development of information and communication technologies poses education to improve the quality of the educational process. And today the main focus in the current learning process is shifting toward the model of e-learning, to which aim mainly to provide students with convenient and round-the-clock access to educational materials, this open access valuable and available e-learning models provides an improved modern learning model that improve the educational process. This study aims to investigate the student's awareness of e-learning and how it is related to self studying and academic achievement. A well-designed online questionnaire developed and used to collect primary data and the statistical analysis has been applied to get the results. The result revealed that the sample students' have high awareness towards e-learning in the University of Jordan and using e-learning significantly affected their self-studying behavior and academic achievement.
\end{abstract}

Keywords: of E-Learning, E-learning, Internet based learning, online learning, self-learning, Academic Achievement

\section{Introduction}

New innovative technologies penetrate more and more deeply into everyday life especially in the educational process the influence of modern information technologies is being rapidly increased, information and communication technology (ICT) are being part of the daily activities of educational process at the universities. A recent trend in higher education is to create and provide online access to course materials. Over the past two decades academics and institutes of higher education have been diversifying their delivery of instruction through ICT such as e-learning management systems(LMS), asynchronous distance learning, and online lessons and exams, and blended learning which can be defined by the combination of traditional face-to-face lectures or tutorials, and web-based course content is better known as "," purporting to blend the best aspects of real and virtual environments (Hamtini, Fakhouri, 2012) (Bielaczyc. 2006)..

Many Jordanian universities have invested in architectures and platforms to support their teaching staff in delivering material to students in a e-learning manner. whereby teaching staff are left to their own devices to supplement their lectures and tutorials with online material, hosted via the university web servers and using typical open source platform such as MOODLE which is used at the university of Jordan for e-learning. (Hamtini, Fakhouri, 2012).

There are factors that influence a student's awareness toward e-learning as well. Self-efficacy, gender, learning style, and job status all impact a student's attitude and decisions about e-learning ( $\mathrm{Lu}, 2010)$. Furthermore, physical and psychological factors can either encourage or hinder students' attitude and success in an e-learning setting (Zandvliet, 2003). Recent studies suggest that including a range of social factors in e-learning, such as what students and instructors believe about learning, should be considered rather than focusing mostly on technology-based tools (Bielaczyc. 2006). From Triandis' (1971) point of view, attitudes consist of three different components: affective, cognitive, and behavioral. The affective component includes statements of likes 
and dislikes about certain objects. The cognitive part refers to statements of a student or instructor that provides rational for the value of an object. The behavioral aspect explains what a student or instructor actually does or intends to do. All of these elements of e-learning help form a students' general awareness toward e-learning, which greatly affects his/her decision to either continue or terminate an e-learning program. (Fatma Alabdullaziz et al., 2011)

E-Learning refers to a variety of ways to learn or train students using ICT tools. Information and communication systems, whether connected or not, are specific media used in the learning process, and there may be no direct contact with people. Even if the equipment and courses continue to progress, this term is still most often cited as the use of technology in the classroom or classroom education experience. In the corporate domain, digital learning refers to the use of corporate networks to provide training courses for employees.

Distance education refers to the use of television and the Internet and other media teaching model, which broke through the boundaries of space, different from the traditional needs of the school to sit in the classroom The teaching model. Students who use this teaching model are usually amateur learners. Because you do not need to attend a particular place, you can attend classes anytime, anywhere. Students can also learn through a variety of different channels through television broadcasting, internet, tutors, classrooms, face-to-face (correspondence) (Bielaczyc, 2006).

\subsection{Types of E- Learning}

Regular (regular) correspondence letter guidance, Synchronous or asynchronous network guide, Via television or radio television courses, $\mathrm{CD}$, students can use the contents of the study, Students are free to access course content via portable mini-computer / mobile phone, and Integrated distance learning, covering online real-time teaching and interactive courses

e- learning has spanned several technological changes in history, such as print, radio, voice or video conferencing, computer-assisted instruction, E-teaching or online teaching, and webcasting. In the broadcast because of its expansion is not yet mature, as in developing e- learning, E-learning initially originated as a system for supporting distance learning. education. The global network was then the only means between the student and the university, so today many call e-learning remote. But we must bear in mind, that e-learning is not just a remote acquisition of knowledge. It presupposes use of educational material and compulsory communication of the student and on the Internet (both in the form of a videoconference in on-line, and in an interactive way). E-education is the possibility of mixed instruction (combining full-time and virtual scenarios), which became the main form of teacher interaction and a student. In this case, there is an electronic component (computer, Internet, information technology) and what directly supported by the communication.

\subsection{Goals, Objectives and Content of the E-Learning Module}

E-learning - study on the basis of developed-scenarios using multimedia and communication technologies. The teacher forms a script, the content of which $s$ the materials that determine the purpose of the training, Up to methods of control. Not only online, but also offline means, for example, CBT equipment. E-learning can be understood as learning, realized with using ICT, more precisely - built on the infrared infrastructure e-learning tools (e-books, online labs works, testing programs, integrated training platforms, etc.).

Application e-learning contributes to the multifaceted enrichment of teaching and study through the effective use of information, communication and media technologies in a wide range of didactic, methodological and organizational scenarios.

The aim of e-learning is to increase the competence, efficiency and quality of preparation of university students, as well as teachers of individual technical and humanitarian disciplines in the field of innovative technologies.

The objectives of the e-learning is: development of theoretical bases and practical skills in the field of innovations in education; development and use of innovative technologies in education; development and use of e-learning tools. (Yang, N. \& Arjomand, L. H. 1999). (Zeitoun, H. 2008).

\subsection{Forms and Motivation for Using E-Learning}

There are various options for e-learning: Teaching in the phase of presence. Possibilities of traditional Teaching can be expanded through the use of multimedia modules for the implementation of the study. The trainee is provided with at the disposal of the relevant information. The training event is temporally and spatially dependent; self-organized study, supported by the media. In that The student is not accompanied by a teacher. The materials of the modules must be independently taken from the network. Study is independent of spatial location and time; Distance courses. With this form of study, all phases of pre-feeding and learning are supported 
by the network. Maintenance of teaching and practical exercises can be implemented interactively on based web technologies. Training is independent of space. placement and time. Visualization of the modular content process within the framework of e-learning. It is a question of audiovisual representation of educational units with the goal of improving the process of cognition (which can lead to a new knowledge) based on the use of films, images, text, sound. (Zhang, D., et al., 2006) (Zemsky, R. Massy, W. 2004).

Self-motivation one of the reasons for the teaching. Anyone who wants to receive knowledge must have motivation to receive them. For this reason, first of all, the goal should be be aware. During lifelong learning, foremost in the following are the motives: effective, application of learning outcomes; personal development; recognition, promotion, etc. In this regard, the educational process should be equipped with modern methods and means, in particular, in universities it should unite the traditional training with a remote e-learning phase, effective remote phase, etc

\subsection{Main Advantages, Disadvantages, Problems and the Myths of E- Learning}

The basis of the educational process for distance learning is a purposeful and controlled intensive self-trainee's work, which can itself determine the successive learn things in a convenient place for themselves, with the individual and, in a number of cases, at a convenient time. Therefore The main advantage of e-learning should be considered a certain freedom in terms of location, learning time and its pace, which makes distance learning is attractive for those users who for one reason or another, do not have the opportunity to study internally, but desire-improve their educational level.

The proportion of self-mastering of the material, the last is particularly important, as it gradually ensures the development of such as independence, responsibility, organization and skill really assess their strengths and make informed decisions, without which a successful career is unthinkable. In addition, e-learning "leads to early mastery of the skills communication technologies, which allows for further significantly improve the efficiency of knowledge use in the economy " (Charlesworth, A. 2002). (Colis, B., and Moonen, J. (2001).

Today, with unprecedented acceleration of information growth E-learning helps to cope with an overabundance, to give absolutely actual knowledge. The use of e-learning allows society and Versions accept the challenges of modern globalization. Educational the paradigm changes very quickly. The ability to transfer knowledge of non-especially for students regardless of geographic location is achieved only through the use of e-learning. Essential advantage is also in the fact that sound, graphics, animation, gipertext, ease of replication, delivery and modernization, context search stimulates the early inclusion of young people in the labor which is very important in terms of solving the employment problem. All this is Benefits include: organization of independent work with electronic material using a personal computer, a PDA, a mobile phone, background, DVD-player, TV; getting advice, advice, assessments from a remote (territory) rially) an expert (teacher), the possibility of a remote actions; the creation of a distributed user community (social networks), leading a common virtual learning activity; Timely round-the-clock delivery of e-learning materials; development of standards and specifications for e-learning materials and technologies, distance learning aids; formation and increase of information (Brown, D., Cromby, J., and Standen, P. 2001). Knowing learners' attitudes regarding e-learning has taken the attention of information system research (Bishop, 2006). Smith, Caputi and Rawstorne (2000) state that "computer attitude is defined as a person's general evaluation or feeling of favourableness or unfavourableness toward computer technologies (i.e. attitude towards objects) and specific computer-related activities (i.e. attitude towards behaviors)" (p. 61). Jones and Issroff (2005) argued that social emotional issues must also be considered when studying elearning.

Federico (2000). In his study on learning styles and network-based instruction he found, "students with assimilating and accommodating learning styles demonstrated significantly more agreeable attitudes and awareness toward varie aspects of network-based instruction than students with converging and diverging learning styles" (Federico, 2000, p. 359). When learners have either positive or negative awarness towards a new technology, those directly affect behavior and therefore the use of the technology, no matter the technology's level of advance (Liaw, Huang, \& Chen, 2007).

This paper investigate The extent to which students have sufficient awareness of e-learning and its relation to self-studying and academic achievement

The rest of this paper is organized as follows section two present the related work, section three present the Research Methodology including Research Population and sampling, Data, Questionnaire design and Data Analysis Method, section four has the Results including Demographic Data Analysis and Analysis of results and finally the Discussion and Conclusion are presented in section five and six respectively. 


\section{Related Work}

Although e-learning environments are popular, there is minimal research on instructors' and learners' attitudes toward these kinds of learning environments (Liaw, 2007) Usefulness and ease of use have proved to be key determinants of the acceptance and usage of e-learning. On the contrary, little is known about students' perceptions in a blended learning setting (Tselios, 2011), University students in developing countries have varying awareness towards e-learning but generally its positive This was emphasised by Nassoura (2012) and he pointed out that many students had positive attitudes towards e-learning because it had a positive impact on their motivation as well as self-esteem. (Nassoura, 2012) (El-Gamal \& El-Aziz, 2011). Afzaal et al., 2017 performed a study about understanding students' attitudes toward e-learning: evidence from bruneian vocational and technical education, their study investigates the 220 students' of technical and vocational institution to assess their attitudes toward e-learning. The study was undertaken in one of the technical institutions in Brunei Darussalam. The study uses the survey methodology and is based upon the questionnaire that was distributed randomly to the students to assess their attitudes towards e-learning and to find out any demographical factors that are significant towards the students' use of e-learning. The result shows that majority of the students have a positive attitudes towards the e-learning with a mean of 3.67. The factor analysis data has suggested two-factor solution on the nine attitudinal items out of the twenty items scale that was initially used to assess the students' attitude.

Yacob (2012) et.al. have examined the awareness of e-learning that involves student from TATI University College in Malaysia. Multiple regression analysis was performed on the students' perceptions in relation to gender, year of study, faculty, technology usage and the awareness of e-learning implementation. The result shows that males and female have a significant awareness towards e-learning in education at TATIUC. Liaw and Huang (2011) explored individual's attitudes and behaviors in using e-learning with regard to gender difference, computer related experience, self-efficacy, and motivation aspects. Ding Aixia and Dan Wang, 2011 study investigated Factors Influencing Learner Attitudes Toward E-learning and Development of E-learning Environment Based on the Integrated E-learning Platform The findings presented that the perception of e-learning is positively influenced by its flexibility in knowledge management, time management and widening access to information. Moreover, an integrated E-learning platform, providing many web-based, multi-platform tools, is introduced based on knowledge management.

Dunbar (2004) described and analyzed the transformation of a face-to face course to an online course using an online learning platform, WebCT. The survey asked students about their preference to have a live instructor or to take the class online. The majority of students responded that they would rather take the online class. Aisbitt and Sangster (2005) described the implementation and effectiveness of a new online assessment system designed to encourage and reinforce the learning of basic principles in an introductory accounting course. A positive correlation was found between student performance in the online assessments and in their final examination. Mcdowall and Jackling (2006) analyzed student perceptions of the usefulness of a Computer-Assisted Learning (CAL) package in learning accounting concepts and its influence on students' academic performance.

Paul G. Paris, 2004 examined the affective, behavioral and cognitive attitudes of 52 Year 10 students from an Adelaide Public Secondary School towards a specific type of online e-learning, that of Online Web-Assisted Learning.

Adewole-Odeshi, Egbe,2014 examined the attitude of students towards e-learning in selected south-west Nigerian universities. Specifically the study looked at the relationship between attitude and e-learning with the application of Technology Acceptance Model (TAM). Questionnaire was used to collect data from a sample of 387 postgraduate and undergraduate students. Findings showed that students have a positive attitude towards e-learning because they find the system.

Lily Wong and Michelle Fong, 2014, investigated the student perceptions of these two methods of delivery in a first-year introductory accounting unit in a number of key areas. These include their perceptions of learning effectiveness, motivation and impact on assessment outcomes. The importance of social interaction and their preference for online learning is also covered. This preliminary analysis of student attitudes will determine whether there are statistically significant differences between face-to-face and online learning options and preference for online learning technology between gender groups. In addition, they investigated whether there are statistically significant relationships between face-to-face or online learning options and preference for online learning technology in gender groups.

\section{Research Methodology}

This study analyzes the extent to which students have sufficient awareness of e-learning and its relation to self-studying and academic achievement. The original sample on which the study tools were applied consisted of 
350 students. In this study, the basic elements of the methodology that are discussed. are illustrated the Data Collection and Response rate, Research Population and sampling, Questionnaire design and the statistical techniques used to interpret the data.

\subsection{Research Population and Sampling}

The population in this research were students enrolled in Jordan Universities, the sample of this research consists of students from the above-mentioned universities. Students are divided into two groups' undergraduate student and graduate students from different majors.

Random Sampling has been used to determine the type of sample used. So each element in the population was had equal chance of being selected as a subject. The size of the representative sample has been calculated using quota sampling to be 350 students out of 90 thousand students.

\subsection{Data Collection:}

The data collected using online questionnaire built using free Forum tool from Google and the link of the questionnaire was provided for students in the computer laboratory.

According to Chisnall 1997, the non-response is a critical limitation of a research, and in order to reduce a non-response rate, the researcher was available at the time of disseminating the questionnaire.

350 questionnaires were distributed on a random sample of graduate and undergraduate students, all questionnaires were filled and analyzed online using google questioner tool. A questionnaire was personally administered to the student in the university. This method is chosen because the designed questionnaire could be collected within a short period of time and any doubts that the respondents might have rapidly could be clarified easily on the spot.

\subsection{Questionnaire Design}

The questionnaire contains Part I that was used to collect the demographic date. Part II have questions that intend to measure the students have awareness about e-learning, self-learning and distance learning, other question paragraphs measure the influencing factors as describe below: The awareness of students towards the use of elements of e-learning in the educational process. The respondents' evaluation of the effectiveness of using the e-learning in the educational process. Difficulties experienced by students in the use of e- learning. Number of disciplines studied using e- learning. The amount of time students spent working in the e- learning environment. Activities / tasks that students performed directly in the e- learning environment. Students' opinion about the use of e-courses in the learning process. and the respondents' evaluation of the effect of using the e-leaning toward self study and self motivation

\subsection{Data Analysis Method}

After collected the data from the respondents, SPSS v.11.5 was used for data analysis statically, reliability analysis and regression analysis were applied in statistical analysis.

Cronbach alpha measure was used to test the reliability of the questionnaire. A value with more than 0.7 means a good consistency. The value of Cronbach's alpha for all paragraphs are higher than 0.7 which indicate an acceptable values of research testing, the reliability in the $70 \%$ range was acceptable and those who were over $80 \%$ were good (Sekaran, 2003).

Descriptive statistics was used which describe a series of observations in a data set parsimoniously, and in a meaningful way, which would enable individuals to get a feel for the basic characteristics of the data. Frequencies, mean, standard deviation and simple linear regression test are the most common descriptive used in data analysis for model building.

\section{Results}

\subsection{Demographic Data Analysis}

The demographic items that were investigated in this research are: gender, age, Education Level, university, field of study, using the internet, using of eLearning, distant learning and self-learning, Table 5.0 shows the Demographic data analysis. 
Table 1. Demographic data analysis

\begin{tabular}{llll}
\hline Demographic Variables & Frequency & percentage \\
\hline Gender & Male & 153 & $43.71 \%$ \\
& Female & 197 & $56.28 \%$ \\
\hline Age & $18-21$ & 210 & $60.00 \%$ \\
& $22-25$ & 95 & $27.14 \%$ \\
& $26-29$ & 33 & $09.42 \%$ \\
& over 29 & 12 & $03.42 \%$ \\
\hline student studying & Undergraduate student & 230 & $65.71 \%$ \\
& Graduate student & 120 & $34.28 \%$ \\
& $1-3$ & 42 & $12.00 \%$ \\
\hline Using the internet & $3-5$ & 206 & $58.85 \%$ \\
(hours per day) & $5+$ & 102 & $29.14 \%$ \\
\hline Using e-learning & $1-3$ & 58 & $16.57 \%$ \\
(Years) & $2-3$ & 122 & $34.85 \%$ \\
& $3-4$ & 77 & $22.0 \%$ \\
& $4+$ & 93 & $26.57 \%$ \\
\hline
\end{tabular}

The demographic characteristics of the respondents are listed in Table 1. It can be observed that $56.28 \%$ of respondents were females and $43.71 \%$ were males. $60.00 \%$ of participants age between 18 to $21,27.14 \%$ were between 20 and 25 years. about $65.71 \%$ of the respondent are Undergraduate student and $34.28 \%$ are Graduate student from master or $\mathrm{PhD}$ level. It can be observed that $34.85 \%$ of the respondent used e-learning for 2 to 3 years, $22.0 \%$ used e-learning from 3 to 4 years and for more than 4 years the rate was $26.57 \%$.

\subsection{Analysis of Results}

The results clearly show a high awareness of using e-learning among the respondents. the significant majority of the students surveyed use of elements e-learning in the educational process of the university.

The awareness of students towards the use of e-learning and the effectiveness of using e-learning in the teaching process are described in table 1. Which shows that the overwhelming majority of students' respondents believe that This is a need now, and in the future for eLearning, and it will become an integral part of the educational process in corresponds to modern models of education, communication and information technology (a total of $97 \%)$.

However, despite this high opinion of students about e-learning, just over a half of the students surveyed believe that the use of e-learning in full-time form is unacceptable (the total of $67.3 \%$ ), and minor number of participants less than $1 \%$ see negative side of the use of e-learning in the educational process of the university. the results shows that, the majority, who participated in the survey, are ready to learn (or are already learning) using electronic courses $(98 \%)$.

Table 2. The awareness of students towards the use of elements of e-learning in the teaching process (at rates, in percent)

\begin{tabular}{lcc}
\hline $\begin{array}{l}\text { The awareness of students towards the use of eLearning in educational } \\
\text { process }\end{array}$ & $\begin{array}{l}\text { Rate of } \\
\text { answer }\end{array}$ & $\begin{array}{c}\text { yes } \\
\text { Rate } \\
\text { answer }\end{array}$ \\
\hline There is a need now, and in the future for eLearning, and it will become an & $97.3 \%$ & $2.7 \%$ \\
integral part of the educational process & & \\
eLearning Is expedient for what I study & $77.2 \%$ & $22.8 \%$ \\
Allows you to more effectively organize learning process & $74.5 \%$ & $25.5 \%$ \\
Allows the use of modern teaching resources & $82.4 \%$ & $17.6 \%$ \\
Increases the level of my ICT competencies & $85.9 \%$ & $14.1 \%$ \\
Corresponds to modern models communication and work with information & $84.5 \%$ & $15.5 \%$ \\
I am ready to be trained (already trained) with using e-learning courses & $98.4 \%$ & $1.6 \%$ \\
Is an extra / extra work & $65.1 \%$ & $34.9 \%$ \\
Use of e-learning elements in full-time educational form not preferable & $67.9 \%$ & $32.1 \%$ \\
I prefer using of e-learning elements as partially with educational method & $88.4 \%$ & $11.6 \%$ \\
\hline
\end{tabular}


Helps you turn to additional educational material e-learning enhanced The educational process by enhancing the $81.9 \%$ 18.1 communication between the teacher and the student Working with the electronic course is a valuable of time and useful the quality of the e-learning course match today's level of education.

E-learning can replace laboratory, practical with a lot of practice and lecture eLearning platform in your university is inconvenient to handle eLearning can be used in all subjects In eLearning The quantity and quality of the knowledge obtained does correspond to the spent Time

e-learning provide access to teaching materials and assignments in 24/7 mode,

$74.3 \%$

$82.7 \%$

$77.8 \%$

$79.5 \%$

$72.3 \%$

$79.7 \%$

$84.2 \%$

$95.7 \%$
$25.7 \%$

$17.3 \%$

$20.5 \%$

$27.7 \%$

$20.3 \%$

$15.8 \%$

$4.3 \%$

The results showed that the participants agreed that there is a need now, and in the future for eLearning, and it will become an integral part of the educational process with rate of $97.3 \%$. it also showed that majority of participants think that eLearning is expedient for what they study and allows you to more effectively organize learning process. The results showed that $82.4 \%$ of participants see that e-learning allows them the use of modern teaching resources and it increases the level of their ICT competencies with rate of $85.9 \%$. the results indicated that eLearning is Correspondent to modern models of communication and work with information with rate of $84.5 \%$. and $81.9 \%$ see that e-learning Helps them to get additional educational material. almost all the participants illustrated that they are ready to be trained (already trained) with using e-learning courses with high rate of $98.4 \%$. but the results of the study indicated that using e-learning is considered an extra / extra work to student with rate of $65.1 \%$. some participants see that the use of e-learning elements in full-time educational form not preferable with rate of $67.9 \%$ and they prefer that it should be integrated with traditional learning as part time teaching method with rate of $88.4 \%$. The results showed that $74.3 \%$ think that e-learning enhanced the educational process by enhancing the communication between the teacher and the student and $82.7 \% \quad$ think that working with the electronic course is a valuable of time and useful. And $79.7 \%$ see that eLearning can be used in all subjects.

The results indicated that the participants see that the quality of the e-learning course match today's level of education with rate of $77.8 \%$. and a rate of $61.5 \%$ see that E-learning can replace laboratory, practical that has a lot practice and experiments. About the eLearning platform in your university $72.3 \%$ see it is inconvenient to handle. $79.7 \%$ of the participants see that eLearning can be used for teaching in all subjects, and 77.8 of them see that in eLearning the quantity of the knowledge obtained does correspond to the spent time.

Table 3. The relation of e-learning and its effect to self-studying and academic achievement

\begin{tabular}{|c|c|c|}
\hline $\begin{array}{l}\text { The relation of e-learning and its effect to self-studying and academic } \\
\text { achievement }\end{array}$ & $\begin{array}{l}\text { Rate of yes } \\
\text { answer }\end{array}$ & $\begin{array}{l}\text { Rate of } n \\
\text { answer }\end{array}$ \\
\hline I prefer to study using e-learning at home & $75.3 \%$ & $24.7 \%$ \\
\hline I don't face difficulties in answering online exams & $81.2 \%$ & $18.8 \%$ \\
\hline $\begin{array}{l}\text { I have good relations inside and outside the university and e-learning } \\
\text { positively affected my relations }\end{array}$ & $74.3 \%$ & $25.7 \%$ \\
\hline In e-learning I can understand the lessons easily & $82.9 \%$ & $17.1 \%$ \\
\hline e-learning gave increased my ability to manage time of studying & $76.3 \%$ & $23.7 \%$ \\
\hline $\begin{array}{l}\text { In e-learning I have the ability to solve my homework using online resources } \\
\text { without the need of any help from anyone }\end{array}$ & $75.2 \%$ & $24.8 \%$ \\
\hline e-learning increased my motivation for studying & $84.2 \%$ & 15.8 \\
\hline I don't feel comfortable when studying with a group of people & $62.1 \%$ & $37.9 \%$ \\
\hline $\begin{array}{l}\text { e-learning increased my Self-learning and made me study by myself and I can } \\
\text { achieve progress suitable for my ability }\end{array}$ & $83.4 \%$ & $16.6 \%$ \\
\hline When I study alone using e-learning I remember lessons better & $84.9 \%$ & $15.1 \%$ \\
\hline e-learning contributes to making learning enjoyable & $88.7 \%$ & $11.3 \%$ \\
\hline $\begin{array}{l}\text { e-learning increased myself challenge toward studding, and learn as much as } \\
\text { possible until complete studying }\end{array}$ & $81.3 \%$ & $18.7 \%$ \\
\hline $\begin{array}{l}\text { e-learning encouraged me to make an effort related to what I learn to my } \\
\text { personal orientation }\end{array}$ & $82.4 \%$ & $17.6 \%$ \\
\hline
\end{tabular}


I do not prefer to discussion and dialogue with my colleagues the e-learning subjects

When I study the subject online I stop from time to time, so I make sure to understand what I read.

e-learning contributes to make my learning faster.

When I study online using e-learning alone I remember things better

I am relieved to know that I will be studying online alone

I love my online work more when I do it on my own without any help from others

$77.2 \% \quad 22.8 \%$

$85.3 \%$

$14.7 \%$

$83.1 \%$

$16.9 \%$

$80.7 \%$

$19.3 \%$

$84.8 \%$

$15.2 \%$

$86.4 \%$

It can be noticed from table 3 that $81.3 \%$ of participants find that prefer to study using e-learning at home and 74.3 have good relations inside and outside the university and e-learning positively affected their relations with other students and people. It can also have observed that the participants who use e-learning can solve my homework using online resources without the need of any help from anyone with rate of $75.2 \%$ and regarding the online exams 81.2 said that they don't face difficulties in answering online exams.

The results showed that most of the participants can understand the lessons using e-learning framework and that e-learning increased their ability to manage time of studying. The results showed also that the overwhelming majority of students believe that e-learning increased their motivation for studying with percent of 84.2 and that e-learning increased their Self-learning and made them study by their self to achieve progress suitable for their abilities with rate of 83.4. a rate of $62.1 \%$ answered that they don't feel comfortable when studying with a group of people. The results showed that 84.9 of the participants remember lessons better When they study alone using e-learning, and that e-learning contributes to making learning enjoyable with arte of 88.7.

It can be also observed from table * that 81.3 of participants find that e-learning increased their self challenge toward studding, and learn as much as possible until complete studying and e-learning encouraged them to make an effort related to what they learn toward their personal orientation with rate of 82.4. the results showed that $77.2 \%$ of participants do not prefer to discussion and dialogue with their colleagues the e-learning subjects. And that $85.3 \%$ of participants stop from time to time, so that they make sure to understand what they read when they study the subject online. The results indicated that the participants see that e-learning contributes to make my learning faster with rate of 83.1. The results also showed that majority of participants think that When they study online using e-learning alone they remember things better and that they are relieved to know that they will be studying online alone. The overwhelming majority of students love their online work more when they do it by themselves.

\section{Discussion}

The research objectives were to find out the students' opinion on the effectiveness use of e-learning process and its effect towered self learning and academic achievements.

Analysis of the data allows us to state that the participants, consider the use of e-learning in the educational the process is uniquely effective. majority of students believe that e-learning is very essential in education process it is now, and in the future, and it will become an integral part in all universities. And they get many benefits from e-learning so that using e-learning Allows them to more effectively organize learning process, to use modern teaching resources, according to (ADEWOLE, 2014) students have a positive attitude towards e-learning because they find the system easy to use and useful for their course work.

The results showed that the participants consider eLearning Is expedient for what they study, and it Corresponds to modern model's communication and work with information, although some of the participants don't prefer to use of e-learning elements in full-time but in part time or integrated with traditional learning methods.

Analysis of the results also showed that almost all of the participants ready to be trained (already trained) with using e-learning courses and they see that e-learning Helps them to get additional educational material. In Jordan e-learning recently widely spread and became effective is and viable form of education with advances in Information and communications technology (ICT), e-learning also enhanced The educational process by enhancing the communication between the teacher and the student and Working with the electronic course is a valuable of time and useful. and Increases the level of their ICT competencies. The study results confirm the presumption of (Dr inż. Colin and Dr Barbara, 2013) that students with a higher appraisal of their competence were more positively inclined towards a wider use of ICT than those with lower levels of ICT knowledge.

The findings showed that the quality of the e-learning course match today's level of education and can be used in 
all subjects and the quantity and quality of the knowledge obtained does not correspond to the spent Time. The participants see that the e-learning platform in the university of Jordan is convenient to handle. The overwhelming majority of students believe that e-learning provide access to teaching materials and assignments in $24 / 7$ mode.

The findings also showed that e-learning contribute to the development of self-studying skills of the participants and it increased their Self-learning and made them study by them self and can achieve progress suitable for their abilities and that e-learning increased their ability to manage time of studying and it increased their motivation for studying. It increased the ability to solve their homework using online resources without the need of any help from anyone and most of the participants prefer to study alone using e-learning and this make them remember lessons better and they prefer to study using e-learning at home.

However, according to in the opinion of respondents e-learning positively affected their relations and they have good relations inside and outside the university, they see that e-learning contributes to making learning enjoyable. According to (Nassoura, 2012) who pointed out that many students had positive attitudes towards e-learning because it had a positive impact on their motivation as well as self-esteem.

The results showed that e-learning encouraged them to make an effort related to what they learn to their personal orientation. Also, most the participants do not prefer to discussion and dialogue with colleagues the e-learning subjects and that e-learning increased their self-challenge toward studding, and learn as much as possible until complete studying.

in the opinion of respondents, however, they don't face difficulties in answering online exams, they can understand the lessons easily, e-learning contributes to make their learning faster, and When they study online using e-learning alone they remember things better.

According to the results, however, participants illustrated that don't feel comfortable when studying with a group of people. And during e-learning studying they stop from time to time, so that make sure to understand what they read. The results also indicated that the participants feel relieved to know that they will be studying online alone and majority of them love their online work more.

\section{Conclusion}

From the above findings of the results from sample of the study and the discussion, it can be deduced that respondents have high awareness of e-learning and it positively affect their self study and academic achievement. Generally speaking, high awareness indicates in a certain degree the possibility that e-learning have major effect on student's behaviors. And this is due to the fact that e-learning has been applied in the university of Jordan very effectively. and that university student are using e-learning for their homework's such as creating visual presentations, presenting written work and researching topics. Deliver it online and communicate through the e-learning platform with students. They are more effective at working independently as a result of e-learning and thus it affect their self-studying to be self dependant, as the results indicated learners were better able to depend on themselves. Generally speaking we can conclude that university students are ready to learn through e-learning platform with many courses hence they have high awareness for e-learning

\section{References}

Adewole-Odeshi, E. (2014). Attitude of Students Towards E-learning in South-West Nigerian Universities: An Application of Technology Acceptance Model. Library Philosophy and Practice (e-journal).

Aisbitt, S., \& Sangster, A. (2005). Using internet-based on-line assessment: A case study. Accounting Education, 14(4), 383-394.

Alabdullaziz, F., Muhammad M. A., Alyahya, S., \& James, E. G. (2011). Learners' Attitudes Toward e-learning within a College of Education, Department of Educational Technology University of Northern Colorado 504 McKee Hall Greeley, CO 80639.

Amjad, A. H., \& Hussam, N. F. (2017). Supernova Optimizer: A Novel Natural Inspired Meta-Heuristic. Modern Applied Science, 12(1). 2018. ISSN 1913-1844 E-ISSN 1913-1852 Published by Canadian Center of Science and Education

Bielaczyc, K. (2006). Designing social infrastructure: Critical issues in creating learning environments with technology. Journal of the Learning Sciences, 15(3), 301-329.

Bishop, J. (2006). Increasing participation in online communities: a framework for human-computer interaction. Computers in Human Behavior, 23, 1881-1893. 
Brown, D., Cromby, J., \& Standen, P. (2001). The effective use of virtual environments in the education and rehabilitation of students with intellectual disabilities. British Journal of Educational Technology, 32(3), 289-299.

Charlesworth, A. (2002). Computer tutor, PC Advisor, pp. 177-181.

Coldwell. (2003). Mapping Pedagogy to Technology - A Simple Model. In Advances in Web-Based Learning ICWL 2003 Vol. 2783 / 2003. Springer-Verlag GmbH. pp.180 - 192

Colis, B., \& Moonen, J. (2001). Flexible learning in a digital world: Experiences and expectations. London: Kogan-Page.

Dhiman, K., Birbal, S., \& Bhim, C. M. (2014). Attitude of University Students towards E-learning in West Bengal. American Journal of Educational Research, 2(8), 669-673. Retrieved from http://pubs.sciepub.com/education/2/8/16 @ Science and Education Publishing

Ding, A., \& Wang, D. (2011). Factors Influencing Learner Attitudes Toward E-learning and Development of E-learning Environment Based on the Integrated E-learning Platform. International Journal of e-Education, e-Business, e-Management and e-Learning, 1(3), August 2011264.

Dunbar, A. E. (2004). Genesis of an online course. Issues in Accounting Education, 19(3), 321-343.

Federico, P. (2000). Learning styles and student attitudes toward various aspects of network-based instruction. Computers in Human Behavior, 16(4), 359-379.

Liaw, S. S. (2007). Understanding computers and the Internet as a work assisted tool. Computers in Human Behavior, 23(1), 399-414.

Liaw, S. S., \& Huang, H. M. (2011). A study of investigating learners attitudes toward e-learning, 5th International Conference on Distance Learning and Education, IPCSIT, vol.12, IACSIT Press, Singapore

Liaw, S. S., Huang, H. M., \& Chen, G. D. (2007). Surveying instructor and learner attitudes toward e-learning. Computers \& Education, 49(4), 1285-1296.

Lu, H. P., \& Chiou, M. J. (2010). The impact of individual differences on e-learning system satisfaction: A contingency approach. British Journal of Educational Technology, 41(2), 307-323.

Mcdowall, T., \& Jackling, B. (2006). The impact of computer-assisted learning on academic grades: An assessment of students' perceptions. Accounting Education, 15(4), 377-389.

Nassoura, A. B. (2012). Students' acceptance of mobile learning for higher education in Saudi Arabia. American Academic \& Scholarly Research Journal, 4(2). Retrieved from http://aasrc.org/aasrj/index.php/aasrj/article/download/248/188

Paul, G. P. (2004). E-Learning: A study on Secondary Students' Attitudes towards Online Web Assisted Learning. International Education Journal, 5(1), 2004.

Rahamat, R., Shah, P. M., Din, R., Puteh, S. N., Aziz, J. A., Norman, H., \& Embi, M. A. (2012). Measuring learners' perceived satisfaction towards e-learning material and environment. WSEAS Transactions on Advances in Engineering Education, 3(9), 72-83. Retrieved May 5, 2013.

Rizik M. H. Al-Sayyed, Hussam N. Fakhouri, Ali Rodan,(2017) Colin Pattinson, Polar Particle Swarm Algorithm for Solving Cloud Data Migration Optimization Problem. Modern Applied Science, 11(8), 2017. ISSN 1913-1844 E-ISSN 1913-1852, Published by Canadian Center of Science and Education

Seyal, A., Mohd, A. S., Awg, H. J., Yussof, H. J., ... Rahman, M. N. (2017). understanding students' attitudes toward e-learning: Evidence from bruneian vocational and technical education.

Smith, B., Caputi, P., \& Rawstorne, P. (2000). Differentiating computer experience and attitudes toward computers: Anempirical investigation. Computers in Human Behavior, 16, 59-81.

Triandis, H. C. (1971). Attitude and attitude change. New York: Wiley.

Tselios, N., Daskalakis, S., \& Papadopoulou, M. (2011). Assessing the Acceptance of a Blended Learning University Course. Educational Technology \& Society, 14(2), 224-235.

Thair M Hamtini, Hussam Nawwaf Fakhouri, (2012). Evaluation of open-source e-Learning platforms based on the Qualitative Weight and Sum approach and Analytic Hierarchy Process, Proc. Int. Multi-Conf. Soc., Cybern. Infor, 2012

Wong, L., \& Fong, M. (2014). Student attitudes to traditional and online methods of delivery. Journal of 
Information Technology Education: Research, 13, 1-13. Retrieved from http://www.jite.org/documents/Vol13/JITEv13ResearchP001-013Wong0515.pdf

Yacob, A., Kadir, A. Z. A., Zainudin, O., \& Zurairah, A. (2012). Student Awareness Towards E-Learning in Education. Procedia - Social and Behavioral Sciences, 67, 93-101.

Yang, N., \& Arjomand, L. H. (1999). Opportunities and Challenges in Computer- Mediated Business Education: An Exploratory Investigation of Online Programs. Academy of Educational Leadership Journal, 3(2), 17-29.

Young, J. R. (1997). Rethinking the Role of the Professor in an Age of High-Tech Tools. The Chronicle of Higher Education, 44(6).

Zandvliet, D. (2003). Learaning envirnments in new conexts: Web-capable classrooms in Canada. In M. S. F. Khine, Darrell (Ed.), Technology-rich learning environments (pp. 133-156). New Jersey: World Scientific.

Zeitoun, H. (2008). E-learning: Concept, Issues, Application, Evaluation, Riyadh: Dar Alsolateahpublication.

Zemsky, R., \& Massy, W. (2004). Thwarted Innovation: What Happened to e-learning and Why. Retrieved from http://www.irhe.upenn.edu

Zhang, D., Zhou, L., BrIggs, R., \& Nunamaker, J. (2006). Instructional video in e-learning: Assessing the impact of interactive video on learning effectiveness. Information \& Management, 43(1), 15-27.

\section{Copyrights}

Copyright for this article is retained by the author(s), with first publication rights granted to the journal.

This is an open-access article distributed under the terms and conditions of the Creative Commons Attribution license (http://creativecommons.org/licenses/by/4.0/). 